NBER WORKING PAPER SERIES

\title{
FROM GROWTH TO GREEN GROWTH - A FRAMEWORK
}

\author{
Stéphane Hallegatte \\ Geoffrey Heal \\ Marianne Fay \\ David Treguer \\ Working Paper 17841 \\ http://www.nber.org/papers/w17841 \\ NATIONAL BUREAU OF ECONOMIC RESEARCH \\ 1050 Massachusetts Avenue \\ Cambridge, MA 02138 \\ February 2012
}

The research in this paper was funded in part by the World Bank and by Meteo-France. The views expressed herein are those of the authors and do not necessarily reflect the views of the World Bank, its executive directors, the countries they represent, or the National Bureau of Economic Research.

NBER working papers are circulated for discussion and comment purposes. They have not been peerreviewed or been subject to the review by the NBER Board of Directors that accompanies official NBER publications.

(C) 2012 by Stéphane Hallegatte, Geoffrey Heal, Marianne Fay, and David Treguer. All rights reserved. Short sections of text, not to exceed two paragraphs, may be quoted without explicit permission provided that full credit, including $(\mathrm{C}$ notice, is given to the source. 
From Growth to Green Growth - a Framework

Stéphane Hallegatte, Geoffrey Heal, Marianne Fay, and David Treguer

NBER Working Paper No. 17841

February 2012

JEL No. D90,Q01,Q32,Q4

\begin{abstract}
$\underline{\text { ABSTRACT }}$
Green growth is about making growth resource-efficient, cleaner and more resilient without slowing it. This paper aims at clarifying this in an analytical framework and proposing foundations for green growth. This framework identifies channels through which green policies can potentially contribute to economic growth. Finally, the paper discusses the policies that can be implemented to capture co-benefits and environmental benefits. Since green growth policies pursue a variety of goals, they are best served by a combination of instruments: price-based policies are important but are only one component in a policy tool-box that can also include norms and regulation, public production and direct investment, information creation and dissemination, education and moral suasion, or industrial and innovation policies.
\end{abstract}

Stéphane Hallegatte

CIRED

45 bis, Avenue de la Belle Gabrielle

94736 Nogent-sur-Marne FRANCE

and Ecole Nationale de la Météorologie Météoromggiy @ worldbank.org

hallegatte@centre-cired.fr

Geoffrey Heal

Graduate School of Business

616 Uris Hall

Columbia University

New York, NY 10027-6902

and NBER

gmh1@ columbia.edu
Marianne Fay

Chief Economist, Sustainable Development Program

The World Bank 1818 H St NW

Washington DC 20433

David Treguer

Sustainable Development Network

The World Bank 1818 H St NW

Washington DC 20433

dtreguer@worldbank.org 
Green growth is about making growth processes resource-efficient, cleaner and more resilient without necessarily slowing them. ${ }^{1}$ This paper clarifies these concepts and proposes analytical foundations for green growth. The "green growth" concept developed here (1) focuses on irreversible actions that might lock the world into patterns that would be prohibitively expensive and complex to modify and (2) seeks to reconcile the short- and the long-term, by offsetting short-term costs and maximizing synergies and economic co-benefits. Finally, the paper discusses the policies that can capture these co-benefits and environmental benefits. Since green growth policies pursue a variety of goals, they are best served by a combination of instruments: price-based policies are important but are only one component in a policy tool-box that can also include norms and regulation, public production and direct investment, information creation and dissemination, education and moral suasion, or industrial and innovation policies.

\section{Green growth as an essential component of sustainable development}

The perception of the importance of growth as a driver for development has changed since the 1992 Rio convention endorsed the notion that, to be sustainable, development had to be balanced across its social, economic and environmental pillars.

Growth-even measured with such an imperfect metric as GDP_is now recognized as a critical driver of poverty reduction and improvements in social indicators. It has resulted in an $80 \%$ increase in GDP per capita in developing countries over the last twenty years despite continued increases in population. Living standards have improved for many, with more than 500 million rising out of poverty and remarkable progress in literacy and education, life expectancy, infant, child and maternal mortality and malnutrition indicators. And while much of the global poverty reduction has been driven by China, other countries that experienced growth also saw rapid poverty reduction. Ghana for example grew much faster than the African average and managed to reduce its poverty rate from 51 to 30 percent between 1990 and 2005.

It also turns out that growth does not cause income inequality-policies do (Milanovic 2011). The evidence does not support the famous Kuznets curve positing that inequality would first increase and then decrease with income. Some countries reduce inequality as they grow; others let it increase. Inequality increased substantially in recent decades in the United States and most of Europe while it declined in much of Latin America.

The implication then is that the links between the economic and social pillars of sustainable development are generally positive. Economic and social improvements tend to go hand in hand, and even more so in the presence of policies to reduce inequality.

The story is not so simple when it comes to the economic and environmental pillars though there are some parallels. In particular, just as with inequality, overall environmental performance doesn't first get

\footnotetext{
1 This expression was forged in the context of the WB's forthcoming environmental strategy which calls for development that is green [which here means resources-efficient], clean and resilient.
} 
worse and then improve with income-no Kuznets curve here. Of course, a number of local and visible environmental public goods do worsen at first and eventually improve with income-typically air and water quality. But this is not true of local pollutants with invisible or long term impacts (e.g. pesticide accumulation), global pollutants (e.g. greenhouse gases) or the destruction of bio-diversity. These get worse with higher income.

So economic growth causes environmental degradation - or has for much of the last 250 years - and will continue to do so without activist policies. Many argue that the policies that would change this would be too costly; that they would slow growth and destroy jobs; that poor countries can't afford them.

However, environmental degradation itself is costly: more than $3 \%$ in Syria, Lebanon, Algeria, Morocco during various years, 8\% of GDP in Iran in 2002 (Croitoru and Sarraf, 2010). Further, much of

environmental destruction is driven by market failures and inefficient policies. Correcting them can therefore result in a more efficient and productive economy, with increased output and prosperity. It may be possible to have green growth without too much of a cost, and possibly with some significant benefits.

Reconciling the three pillars of sustainable development does require policy efforts, particularly for the environmental one. Green growth policies are a critical part of such efforts and an essential part of implementing sustainable development.

\section{Defining green growth}

Green growth is about making growth processes resource-efficient, cleaner and more resilient without necessarily slowing them.

Is it feasible? Environmental protection can make a direct contribution to economic growth because the environment, which we can also think of as natural capital, is an input into the production function, and environmental conservation can lead to increased inputs of natural capital and thus to an increase in income. The use of environmental assets is generally characterized by market failures - external costs and ill-defined property rights being common - and correcting these market failures can increase the effective supply of natural capital hence increasing output; it can also increase human well-being directly by improving air and water quality, something that is not necessarily captured by conventional GDP statistics but is nevertheless the ultimate goal of economic policy.

Indirect contributions of environmental protection to economic growth are also possible because world economies are far from their "optimum." Indeed, there are many market failures that are not directly due to environmental issues, but that have negative consequences on the environment and the economy. Correcting these market failures thus has co-benefits that go beyond the environment. An obvious example is urban congestion, causing air pollution and also reducing the productivity and economies of scope typically offered by cities.

These phenomena are not normally captured in analytical models of economic growth, partly because these do not generally model the role of natural capital in economic growth, and partly because they 
assume a first-best world with no market failures. Moreover, the specification of the micro foundations of the growth process is at best weak in aggregative growth models. Since the potential for accelerated income growth thanks to green growth policies arises from market failures, they cannot be assessed using models unable to represent these market failures. Only models that represent unemployment and imperfection in the labor market can for instance investigate the gains from green policies in terms of jobs and employment.

This paper aims at clarifying these concepts in an analytical framework and at proposing foundations for green growth, starting from and building on the long tradition of adapting growth theory to include the environment (e.g., Nordhaus, 1972; Dasgupta and Heal, 1974; Solow, 1974).

The next section examines the analytical case for green growth, putting it in the context of existing growth paradigms. We then discuss the link with welfare, which is what we care about rather than growth per se. Section 4 explains the flaws in the "grow now, clean up later" argument and presents the analytical case for urgency. Section 5 reviews policy instruments to push our economies towards greener growth path, arguing that a narrow reliance on prices will not solve problems characterized by multiple market failures and behavioral challenges and that green strategies must rely on a broad policy mix.

The last section concludes with key findings:

- There is a strong analytical case for green growth, and one can identify channels that are theoretically able to make green policies contribute to economic growth; however, detailed and country- and context-specific analyses of each of these channels are required to conclude that this will in fact happen in any specific situation.

- Looking at economic development and environmental protection in a common framework enables us to identify substantial synergies between them.

- Social and political acceptability of green growth policies requires maximizing and highlighting benefits and co-benefits, including potential positive impacts on poverty alleviation and job creation, as well as managing unavoidable trade-offs.

- Green growth policies should focus on what happens over the next 5-10 years, a period in which the world may be locked into settlement and production patterns that would be prohibitively expensive and complex to modify.

\section{Is it really possible to green growth? The analytical basis}

Classical growth theory (Solow, 1954) assumes that output $Y$ is produced using technology and human capital A, physical capital $K$, and labor $L$. The relationship often reads:

$$
Y=f(A, K, L)
$$

with $d Y / d A>0 ; d Y / d K>0 ;$ and $d Y / d L>0$. 
Output growth $\mathrm{dY} / \mathrm{dt}$ is explained by growth in production factors $\mathrm{K}$ and $\mathrm{L}$, and growth in productivity $\mathrm{A}$. Growth in labor $L$ is explained by population growth, labor force participation and improvements in health and education.

Growth in $\mathrm{K}$ is explained by investment, and growth models assume that a share of output is used to increase the stock of capital K:

$$
\begin{gathered}
Y=C+I, \\
d K / d t=I-\delta K,
\end{gathered}
$$

where $\delta$ represent the obsolescence and depreciation of capital. Growth in $A$ is explained by technological change, including changes in organization and practices, and by social capital improvement (better institutions, social cohesion, etc.).

In some growth theory models (e.g., the Solow model of 1956), labor and total productivity growth is exogenous. In others models (e.g., Arrow, 1962; Lucas, 1988; Romer, 1990 and 1994; Mankiw et al., 1992; Aghion and Howitt, 1998), productivity growth is endogenous and depends on investments in education, research and development, on the scale of output and on learning by doing. Economic policies can influence accumulation of physical capital, social capital, and human capital to maximize output or to maximize the growth in output (i.e. GDP growth).

In this approach, the environment has no productive role, although it can enter through the utility function through its amenity value.

\section{Environment enters as a factor in the production function}

The idea that economic production is directly dependent on the stock of natural resources and on environmental quality-- i.e. that the environment is an argument of the production function -- has been around at least since Malthus (Malthus, 1798) and further developed in a well-developed environmental economics literature that took off in the early 1970s (Nordhaus, 1972; Dasgupta and Heal, 1974; Solow, 1974). ${ }^{2}$

This modification of classical growth theory focuses on the constraints created by exhaustible resources and views the environment mostly as a limiting factor-either because of its finite ability to produce resources or its finite ability to absorb waste (for a survey, see Brock and Taylor, 2005). The tone can be more positive-with healthier soils and greater water quantity, agriculture is more productive; with improved air and water quality, the population is healthier and more productive; with better land use management, natural disasters can be averted and death and destruction avoided etc-but the basic idea is the same.

Whatever the emphasis, this approach stresses the services provided by ecosystems, beyond their amenity functions (which enter into the utility function). The environment becomes "natural capital",

${ }^{2}$ Later efforts to explicitly model the environment into an endogenous growth framework include Smulders (1994) and Bovenberg and Smulders (1996); for a review, see Smulders (1999). 
directly needed for growth. And environmental management becomes a productive investment, directly comparable to investment in physical capital. A failure to manage the environment results in the depreciation and destruction of natural capital, with direct impacts on output.

We thus have:

$$
\begin{aligned}
& Y=f(\mathrm{~A}, \mathrm{~K}, \mathrm{~L}, \mathrm{E}) \\
& \text { with } \mathrm{d} Y / d E>0
\end{aligned}
$$

A key question in this framework is the extent to which production factors are complements or substitutes: if substitutes, destruction of the environment can be compensated by investing more in physical or human capital or in technical change; if complements (or weak substitutes), then protecting the environment is necessary to maintain economic production.

There are few studies of the potential for substituting other inputs for natural capital, though it is generally accepted that it has limits. Soil and water are necessary for food production even if technology and increased labor intensity can reduce the quantities needed. A low elasticity of substitution between natural capital and other inputs implies a small increase in the former can free large quantities of the latter. To be precise, if we think of two inputs to production, natural capital $E$ and other inputs $O$ (including labor and physical capital), then if natural capital is scarce and the elasticity of substitution is close to zero, the ratio of the marginal product of natural capital to that of other inputs is very high and a small rise in E substitutes for a large quantity of $\mathrm{O}$. Formally if the production function is a Constant Elasticity of Substitution (CES) function with:

$$
Y=A\left[\alpha O^{1-\frac{1}{\varphi}}+(1-\alpha) E^{1-\frac{1}{\varphi}}\right]^{\frac{\varphi}{\varphi-1}}
$$

Then, the relationship between the marginal product of $E$ and that of $O$ is

$$
M P_{E}=M P_{O}\left(\frac{1-\alpha}{\alpha}\right)\left(\frac{O}{E}\right)^{\frac{1}{\varphi}}
$$

This marginal product goes to infinity as the ratio of $O$ to $E$ increases and the elasticity goes to zero, so that if environmental capital is scarce and other inputs abundant, the marginal value of extra environmental capital can be very large. ${ }^{3}$

Dasgupta and Heal (1979, p. 196) make a distinction between exhaustible resources that are essential or inessential: a resource is inessential if it is possible to produce positive consumption for ever without it, and it is essential if in this case consumption must eventually decline to zero. Whether a resource is

\footnotetext{
${ }^{3}$ Sometimes, it is useful to distinguish between short-term and long-term substitution. It may be possible to substitute a loss of natural capital with other capitals under the short-term, but not over the long-term. For instance, using more fertilizers can compensate for soil degradation over the short-term, but is not a long-term solution.
} 
essential or inessential depends on the elasticity of substitution between the resources and other inputs. If this is low enough it is essential.

One extreme case is the risk of catastrophe. An environmental catastrophe may mean that all economic production becomes impossible:

$$
\begin{gathered}
\operatorname{Lim} Y(A, K, L, E)=0 \\
E \rightarrow E^{*}
\end{gathered}
$$

In the absence of market failures-i.e. if all environmental externalities were internalizedenvironmental assets would have a price and a "Green GDP" could be calculated by introducing the environment into national accounts. ${ }^{4}$ Unfortunately, environmental externalities, market failures and technical and ethical issues in calculating the "price" of environmental assets complicate the calculation of this Green GDP.

One question is whether investing in the environment increases only the level of production, or also its growth. The answer is likely to be context specific. As explained by Rodrik and Subramanian (2008), an increase in production increases income and savings, and thus accelerates growth where production growth is limited by credit constraints (i.e. desirable and profitable investment opportunities exist but cannot be realized due to a lack of savings and inadequate access to capital markets). Not so where output growth is limited by investment opportunities (because institutions are not in place to allow investors to benefit from their investment revenues): where people are engaged in low-return activities an increase in production level will not translate into an increase in economic growth because economic activity does not generate sufficient returns to allow households to save and accumulate assets.

\section{Green policies as a source of growth}

So far we have modeled the positive impact of environmental policies on economic output as operating through an improvement in environmental conditions: better forestry management reduces soil erosion leading to more productive agriculture. Environmental policies are not specifically included in the production function-only their impact on E; and their only impact is, in fact, on the environment. However, environmental policies may themselves have externalities and impact growth through channels other than an improvement in the quantity or quality of environmental inputs.

A broader framework, closer to reality, accounts for the fact that in practice real-world economies are far from their optimal, or first-best state due to market failure and other sub-optimalities such as:

- Knowledge spill-overs and economies of scale that lead to under-investments in research and development (e.g., Aghion and Howitt, 1992);

- Under-utilization of production factors (physical capital or labor through unemployment) for temporary (crisis) or structural reasons;

\footnotetext{
${ }^{4}$ For a review of the literature on the integration of the environment in national accounts, see Heal and Kriström (2005). See also an application of these ideas in World Bank (2006).
} 
- Behavioral biases maintaining the economy away from its optimal equilibrium (e.g., inability to make decisions concerning low-probability events, Magat et al., 1987; Camerer and Kunreuther, 1989; Hogarth and Kunreuther, 1995; Tversky and Shafir 1992).

Policies can contribute to growth if they help correct these sub-optimalities. As such, green growth policies can be defined as policies that address sub-optimalities, hence contribute to growth, while at the same time protecting the environment. Most are environmental policies in the sense that their primary objective is the preservation of the environment - but not all (e.g. energy security policies; policies to reduce urban congestion...)

To represent the role of green policies, our growth model needs to be designed in a second-best framework, in which there are market failures and the economy is not at its optimal equilibrium. To do so, we introduce two changes in the production function. First, we assume that $f$ is not the current production function, but the production frontier, i.e. the maximum possible production level possible with the available technology, physical capital, labor, and environment, assuming maximum efficiency. Actual production is given by:

$$
Y=\psi f(A, K, L, E),
$$

Here $\psi$ measures the efficiency of the production process, and lies between 0 and 1 . Over the short term, $\psi$ can also include demand-led and Keynesian effects, when actual production is more constrained by demand than by production capacity (i.e., in situation of high unemployment and low utilization of production capital).

Second, we introduce $P_{E}$, which can be thought of as the effort dedicated to environmental policies, in the production function:

$$
Y=\psi\left(P_{E}\right) f\left(A\left(P_{E}\right), K\left(P_{E}\right), L\left(P_{E}\right), E\left(P_{E}\right)\right)
$$

The costs (or disutility) associated with environmental efforts create a trade-off between environmental protection and economic production. They may:

- $\quad$ Reduce productivity (A), by causing producers to use more expensive or less productive technologies (e.g. renewable energy sources that may be more costly than coal).

- $\quad$ Result in the early retirement of physical capital $(K)$ if the capital is based on polluting technologies (Grubb et al. 1995, Jaccard and River 2007). This effect can be represented as a decrease in $\mathrm{K}$ or an increase in capital depreciation. In addition to the direct cost, the increase in investment needed to replace retired capital reduces consumption, thus welfare, at least over the short term.

- Increase the price of some goods and services, and alter relative prices. Doing so, they change the structure of demand, making the structure of production less able to serve it. Demand may decrease in some sectors that have a high production capacity (e.g., road transport) and increase in other sectors that have a more limited production 
capacity (e.g., public transportation). This effect can be measured as a reduction in efficiency, i.e. a reduction in $\psi$.

These costs-and their assessment-are dependent on the definition of economic output $Y$. In a green accounting framework, a reduction in economic productivity due to environmental regulations can be more than compensated by a reduction in external effects which leads for example to the preservation of ecosystem services. If $Y$ (and $A$ ) includes ecosystem services, then the total impact of the regulation can be an increase in $Y$ (and $A)$.

Environmental policies can also increase conventionally measured economic output (GDP) if they:

i. Increase the effective quantity of production inputs $\mathrm{K}, \mathrm{L}$, and $\mathrm{E}$. The impact of environmental policies on $E$ is obvious since improving $E$ is their main objective. But environmental policies can also increase $L$, for instance because better water and air quality improves worker health (Hanna, 2011). They can also increase $\mathrm{K}$, because well-managed natural risks lead to lower capital losses from natural disasters (Hallegatte et al., 2007; Hallegatte, 2011).

ii. Produce productivity gains by correcting the many market failures affecting the environmental sphere and enhancing efficiency of resource use (i.e., increasing $\psi$ ), thereby reducing production costs and increasing productivity and competitiveness, or playing a stimulus role. Gillingham et al. (2009) shows how green policies targeting energy efficiency can achieve their objectives at negative cost. Zenghelis (2011) proposes the use of green policies as a stimulus in countries in recession.

iii. Shift the production frontier by accelerating the development and dissemination of innovations, and creating knowledge spillover in the entire economy, thereby increase $A .{ }^{5}$ Since investments in knowledge tends to be lower than desirable in the absence of public intervention, policies targeting green technologies can usefully increase R\&D investments (Gerlagh, 2006; Otto et al., 2008; Fischer and Newell, 2008; Acemoglu et al., 2011). ${ }^{6}$

These three positive factors are shown in Figure 2.

\footnotetext{
5 This argument on the impact of green policies on productivity is the macro-scale equivalent of the Porter Hypothsis (Porter and van de Linde, 1995), who states that regulation can enhance innovation and business performance at the micro-scale (see a review in Ambec et al., 2011).

${ }^{6}$ A frequently asked question is whether green innovation needs public support specifically targeted towards green innovation or more generally towards innovation. Here we actually ask the opposite question can green innovation policies accelerate innovation in general?
} 
Figure 2: The effect of green policies on output. The arrow (i) represents the increase in production factor; (ii) represents the enhanced efficiency; and (iii) represents the shift in production frontier.
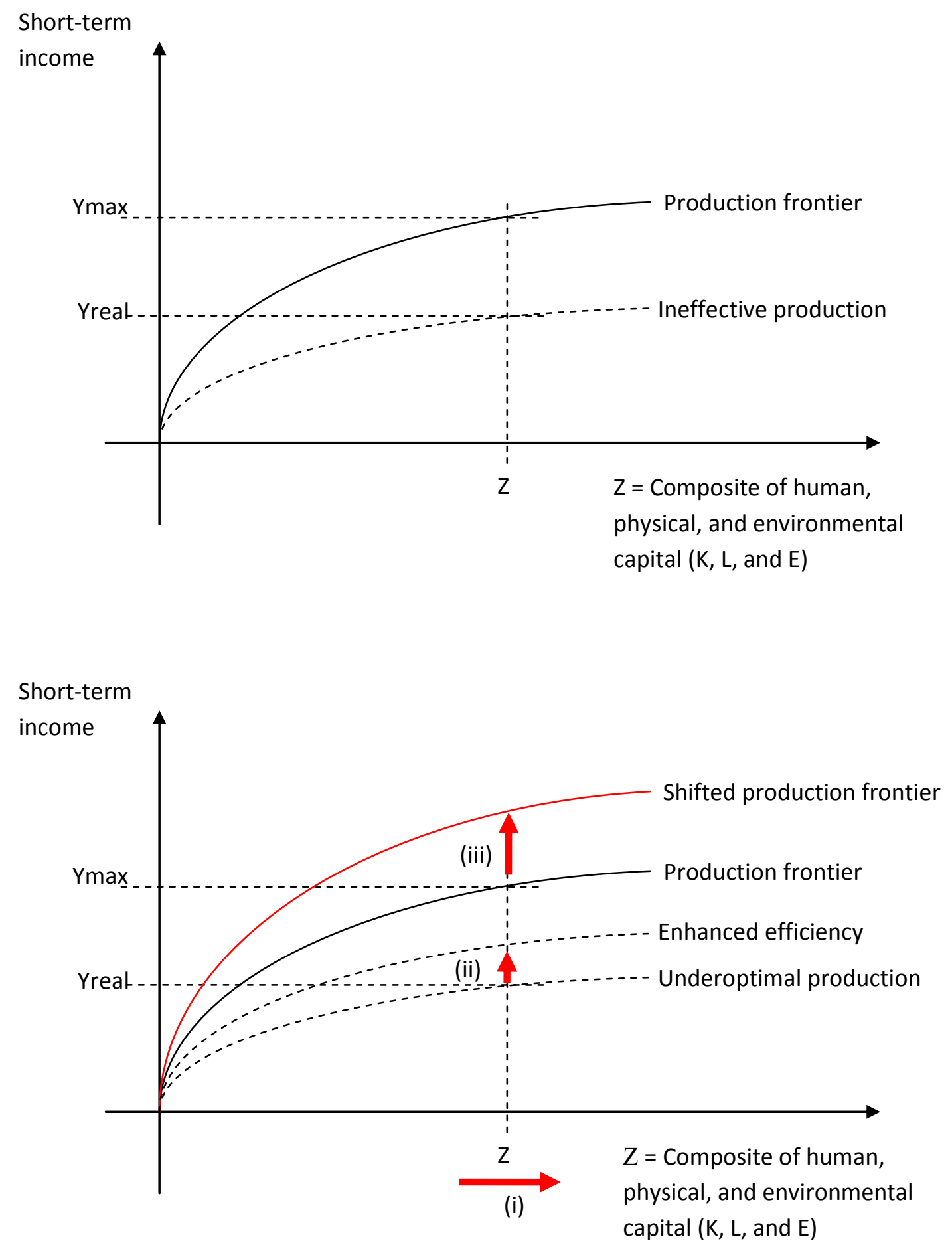
We can represent these positive effects analytically by differentiating the production function totally with respect to environmental policy, giving as the impact of a change in environmental policy:

$$
\frac{d Y}{d P_{E}}=\psi^{\prime} f+\psi\left[f_{A} A^{\prime}+f_{K} K^{\prime}+f_{L} L^{\prime}+f_{E} E^{\prime}\right]
$$

where a prime denotes the derivative of a function of one variable, $f_{X}$ is the marginal product of the capital X (for K, L and E) or of productivity (for A).

Thus, $\psi f_{E} E^{\prime}$ is the direct benefit from the environmental policy, while $\psi^{\prime} f, \psi f_{A} \mathrm{~A}^{\prime}, \psi f_{K} K^{\prime}$ and $\psi f_{L} \mathrm{~L}^{\prime}$ are the different co-benefits. This formula identifies five channels through which environmental policy affects output: its impacts on

- $\quad$ Capital stock $\left(\psi f_{K} K^{\prime}\right)$

- Labor force $\left(\psi f_{L} L^{\prime}\right)$

- Natural capital $\left(\psi f_{E} E^{\prime}\right)$

- Efficiency and demand-led effects $\left(\psi^{\prime} f\right)$

- Technology and intellectual capital $\left(\psi f_{A} \mathrm{~A}^{\prime}\right)$

An example of the efficiency link $\left(\psi^{\prime} f\right)$ is offered by energy efficiency. There is evidence that many costeffective investments - that reduce energy consumption at a negative cost - are not implemented by households in the residential sector. There are competing explanations for these inefficiencies, but they are likely linked to market failures and behavioral biases (Gillingham et al., 2009; Box 7). Environmental policies aiming at reducing energy consumption and carbon emissions may correct these market failures or influence these behaviors, leading to less environmental damages and to a more efficient economy, with a higher growth potential.

There are many other examples of inefficiencies that can be corrected with both environmental and economic benefits. Having functioning land markets with secure land tenure would help provide services to informal settlers (including solid waste removal, sanitation and drainage, drinking water). Beyond environmental benefits (e.g., in terms of water pollution), this would increase welfare and labor productivity, and the overall functioning of the economy (for instance because land tenure increases access to credit for poor households and makes it possible for them to invest in small businesses).

Since $\psi$ also includes demand-led effects, the channel $\psi^{\prime} f$ also includes stimulus effects. An environmental policy can have macroeconomic benefit through a stimulus effect during an economic recession, when capacity utilization and employment is low, and when the policy is demand-increasing, for instance because it implies large investments in green infrastructure (Zenghelis, 2011).

The link through technology and intellectual capital $\left(\psi f_{A} A^{\prime}\right)$ is illustrated in Box 1 , with investment in $R \& D$ on photovoltaic power motivated by a desire to mitigate greenhouse gas emissions and reduce climate change. Success could make photovoltaics competitive with fossil fuels and increase the supply 
of electric power, and indeed reduce the cost of providing electric power to remote off-grid communities. Theoretically, however, the opposite effect is also possible, as research on "green" technologies could crowd out research focused on productivity-increasing technologies (Popp et al., 2009).

\section{Box 1. Solar Panels - Distributed Power Generation}

Solar energy may soon replicate one of the most remarkable success stories of the last few decades, the growth of mobile phone use in developing countries. For countries with no land-lines, cellular phones have a great advantage. They require less capital investment and can be deployed faster. The extraordinary growth of mobile communications has provided a platform on which many other services are now carried, including mobile banking, access to market data and to medical advice. Today the conditions are ripe for a repeat of this distributed deployment of infrastructure, but in the field of power generation rather than communication. In that case, technological developments that have been promoted for environmental reasons may lead to technological change that increases the overall productivity of the economy (even if output is defined in a narrow sense). In this example, the impact of environmental policy on economic growth is captured by the term $\psi f_{A} A^{\prime}$ of Equation (2).

Solar power has many of the characteristics that allowed mobile phones to be deployed so fast. The cost has fallen dramatically in the past five years, from $\$ 8$ per watt of capacity to about $\$ 1.70$, leading to a levelized cost of electricity in the US of about 10-12 cents per kilowatt hour. [Power from wind or gas costs about 5-6 cents, from coal about 6-8 cents, per kilowatt hour. The retail price of power is around 15 cents.] There are few economies of scale to the deployment of solar power, and so few economic penalties to small-scale use, and in general it is deployed at the demand site ["off grid"], obviating the need for power grids.

Solar power is therefore ideally suited to southern developing countries with high levels of solar radiation and no power infrastructure in place in rural areas: the total cost of deploying solar power in rural areas is less than that of conventional power stations plus a grid [which in the US costs about \$3 million per mile]. Solar's drawback is that is ceases when the sun sets, and so needs to be accompanied by batteries that can store power into the night.

Solar power is already available in some rural developing countries. In the Iquitos region of Peru, along the upper reaches of the Amazon, the provincial government and NGOs have combined to make solar panels, batteries and compact fluorescent bulbs available to households at less than the cost of fuel for the generators they were previously using for power. Electricity is now available at zero marginal cost, encouraging use, and with no environmental impact. In Bangladesh an ex employee of the Grameen Bank runs Bright Green Energy, which sells solar panels and batteries, provides financing in conjunction with the IFC and local banks, and in conjunction with Grameen Technology Center trains women to install and service solar power sources.

The labor force link $\left(\psi f_{L} L^{\prime}\right)$ can work through the effect of environment on health. Better environmental policies can reduce atmospheric pollution in cities, reduce respiratory diseases, and increase labor effectiveness and reduce days lost due to illness. Graff Zivin and Neidell (2011) provide an example of this link between air pollution (in that case, ozone) and labor productivity in farms in California. Using a database of daily worker output, they find a surprisingly strong impact, with a $10 \mathrm{ppb}$ decrease in ozone concentrations increasing worker productivity by 4.2 percent.

As an illustration of how environmental policies may increase capital and its productivity $\left(\psi f_{K} K^{\prime}\right)$, one only has to think of mitigating climate change and the way in which this will prevent economic impacts 
(including, e.g., increased disaster losses in some regions, and possible declines in the productivity of agriculture and the capital equipment associated with it), or of improved water management that increase the productivity of water-using activities. Another example is linked to natural disasters: protecting mangroves can improve resilience of coastal zones to hurricanes and storm surges, thus reducing capital losses due to coastal floods.

As an illustration of the natural capital link $\left(\psi f_{E} E^{\prime}\right)$, consider fisheries, where the introduction of individual transferable quotas has helped to maintain the resource stock, and thus the economic activity that is dependent on it (Box 2).

\section{Box 2: Individual Transferable Quotas (ITQs)}

We noted in the main text that environmental policies could affect the supply of natural capital, this effect being captured by the term $\psi f_{E} E^{\prime}$ ) in Equation (2). ITQs provide a good illustration of this point: they are a policy that corrects an environmental problem, lack of property rights leading to overfishing, and there is clear evidence that they lead to an increase in the output of and employment in the fishing industry.

ITQs operate by setting a cap on the total allowable catch (referred to as TAC). This is set at a level that is consistent with the long-term survival of the species. So the general rule used here has been to try and set a cap that is less than the rate of growth of the fish stock. To make the process of setting a cap clearer, let's suppose we have a fish stock of 10,000 tons and that this grows by about $10 \%$ or 1,000 tons per year. Then the TAC should be set at or below 1,000 tons: this way we remove 1,000 tons every year but the population grows by this amount and the total remains constant: we have a rule that is compatible with the long-run survival of the species. The increment to the population is sometimes referred to as the maximum sustainable yield: it's the largest catch that will sustain the population.

In practice matters are a bit more complicated: humans are not the only species that catch fish. Sea birds and marine mammals - sea lions, sea otters, seals - also eat fish, as do a wide range of large predatory fish such as tuna and swordfish. If the ocean is to remain productive and healthy we have to allow all these other species to eat their fill too. So we need to come below the maximum sustainable yield.

Once a TAC is set, this is divided into individual quotas, amounts that can be caught by particular boats or skippers. Only quota owners can fish, and they cannot catch more than their quota. Continuing our earlier example, we might allocated ten percent of the TAC to each of ten boats, allowing each in this case to catch 100 tons each year: if each abides by its catch quota then the total is within the TAC. So an individual quota is a fraction of the TAC to which a boat or skipper is entitled. If the TAC changes from year to year then the number of tons represented by the quota also changes, though the fraction of the TAC does not.

These quotas are transferable, that is they can be sold (or given or left in a will) to others. The really central point here is that their value depends on the productivity of a fishery: $1 \%$ of a thriving and productive fishery with large fish stocks is worth far more than $1 \%$ of an almost-extinct fishery. So quota-owners - fishermen - now have an investment in the long-run health of their fishery. The quotas are generally a major part of their wealth and if they overexploit the fishery then they impoverish themselves. They do now have an incentive to leave fish in the water to breed and generate future catch, something that they otherwise lack. ITQs align the interests of fishermen and the fishery, and generally raise both the health of the fishery and the profits of those who fish it. An approach related to ITQs is that of "catch shares:" each boat or owner is entitled to a share of the TAC, but these are not 
transferable. So they aren't liquid assets like ITQs, but do have many of the same effects as ITQs: they are assets whose value depends on the health of the fishery.

The results of implementing systems of ITQs have been dramatic. A recent study looked at the histories of over 11,000 fisheries, of which 121 had instituted ITQs at the time of the study. ${ }^{7}$ Most of the ITQs were on the New Zealand coastal shelf, the Icelandic coastal shelf and in the Gulf of Alaska, some of the world's most productive fisheries. The data shows a dramatic increase in catch within a few years of the implementation of an ITQ, and a great decease in the chance of a fishery collapsing once it is managed as an ITQ. On average, within seventeen years of implementing an ITQ (seventeen was the number of years of data available at the time of the study), the catch on fisheries with ITQS rose by a factor of five, that is, by four hundred percent. In some cases yields were up by as much as a factor of two hundred. So the fisheries prospered and generated a better living for those who worked in them, and of course more food for the rest of us. This is immensely encouraging: we do know how to manage fisheries, and the fact that so many are still grossly overexploited reflects a lack of political will rather than an insuperable economic problem in the management of common property resources. (Heal and Schlenker, Nature 2008).

\section{What about welfare?}

A distinction needs to be made between environmental impacts that affect welfare through their impact on income and consumption and those that do so through the amenity value of environmental assets. Poor urban households who struggle to feed and house themselves will place a lower priority on the amenities provided by an urban park than rich households might. However, they care deeply about the absence of solid waste management and its results-dengue epidemics, clogged urban drains that lead to floods and the destruction of their homes and small business equipments. In rural areas, protecting forests for the purpose of preserving rare animals may not be a priority for households who struggle to feed themselves (unless of course the poor can share in the benefits from wildlife protection). But the same households care about protecting soil quality and managing water flows, which allow them to grow crops. The former environmental goods affect utility only. The latter affect income and production capacity and cannot be considered as superior goods.

\footnotetext{
${ }^{7}$ Costello et al. (2008) and Heal and Schlenker (2008).
} 
Ultimately we care about welfare, not output, so the next step is to take into account the impact of output on welfare (or utility, U). Since investment does not increase welfare directly, we can assume that utility depends only on the current level of consumption C:

$$
\mathrm{U}=\mathrm{u}(\mathrm{C}),
$$

with $\mathrm{du} / \mathrm{dC}>0$.

One policy goal then should be to maximize $U^{\infty}$, the discounted sum of $U$ from the present to the infinite future: ${ }^{8}$

$$
U^{\infty}=\int e^{-\rho t} U(C(t))
$$

Here $\rho$ is the pure rate of time preference. In the Ramsey-Cass-Koopman model, investment $I(t)$ is such that the discounted sum of utility is maximized. If the production function and the utility function respect certain conditions, and if labor $L$ and productivity $A$ grow a constant rates, then the economy converges toward a balanced growth path, the rate of which is entirely determined by labor and productivity growth rates.

Starting from this very basic growth theory, one can introduce environmental management in the picture. E becomes a measure of environmental quality that is endogenous to the model and is affected by current and cumulative production. Typically $\mathrm{E}$ would be a decreasing function of both $\mathrm{Y}$ and its integral, reflecting the idea that production generates both a stock and a flow of environmental damage.

The framework can also be augmented to account for the fact that environmental protection can also be justified on amenity grounds. This means assuming the environment needs to be preserved because people derive utility from it directly-watching a sunset, visiting a protected area, etc. In that case, we have:

$$
U=u(C, E),
$$

with $d u / d E>0$.

The risk of an environmental catastrophe can be represented by $U$ going to negative infinitely when environmental quality is too degraded:

$$
\begin{gathered}
\operatorname{Lim} U(C, E)=-\infty \\
E \rightarrow E^{*}
\end{gathered}
$$

\footnotetext{
${ }^{8}$ In fact, the definition of $\mathbf{U}^{\infty}$ includes all questions related to inter-temporal distribution, and different approaches co-exist, from the discounted-utility presented here (with debates about the right discount rate for environmental issues), to Rawlsian criterion.
} 
We then want to maximize $\mathbf{U}^{\infty}$ which now directly depends on $\mathrm{E}$ :

$$
\operatorname{Max} \int \mathrm{e}^{-\rho t} \mathrm{U}(\mathrm{C}, \mathrm{E})
$$

But utility does not only depend on the average, aggregated level of consumption, and on the environment. In practice, it is possible that environmental policies affect utility directly (e.g., by creating jobs), with effects that are not mediated by aggregated consumption and the state of the environment:

$$
U=u\left(C, E, P_{E}\right)
$$

We still want to maximize $\mathbf{U}^{\infty}$, but in that case we take into account possible effects of environmental policies. As for growth, environmental policies $\mathrm{P}_{\mathrm{E}}$ can have negative or positive impacts on utility. For instance, distribution (how total consumption is distributed across individuals) and volatility (how total consumption is distributed over time) also matter for welfare. Everything else being equal, many favor stable consumption patterns and lower consumption inequality. ${ }^{9}$ Introducing these additional factors in the utility function leads to two additional impacts of environmental policies on welfare.

Regarding distribution, environmental policies-for instance higher energy prices because the environmental externality is internalized-have income and distributive effects (Box 3). They may lead to job destruction for example in polluting industries. But - under conditions heatedly debated in the scientific community - environmental policies may also lead to net job creations in countries where unemployment is a serious problem and help alleviate poverty. Also, women are found to be more dependent on common property resources and more vulnerable to the negative externalities of natural resource degradation (Foa, 2009). Environment protection and green policies can thus contribute to improved gender equality, with many economic and social co-benefits.

This creates both social and political economy issues and may require the implementation of complementary policies that aim at compensating losers (see Box 3 ). If lump-sum transfers are possible at zero cost and labor markets are perfect, efficiency can be separated from equity. If lump-sum transfers are impossible or costly and if labor markets are imperfect, then a combined investigation of efficiency and equity becomes necessary

Box 3: Distributional impact of climate policies, and possible complementary measures: lessons from energy subsidy removal and modeling exercises.

Climate policies may have negative distributional impacts within countries, but there are also complementary policies that can be implemented to compensate their possible negative impacts.

In first-best contexts, it is possible to separate efficiency and equity issues in policies (Harberger, 1978), because it is possible to make zero-cost lump-sum transfers. Indeed, if such transfers are possible, then ex post transfers can cancel any undesirable distributional impact. Such transfers meet however many difficulties: political acceptability (Kambur, 2010), information and technical issues (Sen, 1973, 1976; Bourguignon and Fields, 1990) and behavioral

\footnotetext{
${ }^{9}$ The utility function can for instance include an aversion for inequality.
} 
changes can make such transfers impossible. In absence of such transfers, the distribution effects of climate policies need to be taken into account in the design of the policy.

The experience from removal of fossil fuel subsidies illustrates well the possibilities and limits of ex post correction of negative income impacts. Typically the largest share of fossil fuel subsidies goes to the better-off (the poor consume much less energy, seldom own cars and may not even have access to electricity) so that a removal of the subsidies has a positive distributional impact. However, the subsidies are also often a significant share of the poor's income so that a removal can have a very negative welfare impact on the poor and the near poor (Coady et al., 2006; Freund and Wallich, 1995; Hope and Singh, 1995). In such cases complementary policies are critical to not only increase political acceptability but ensure the poor are not subject to unacceptable price shocks. These policies include the use of existing safety nets, alternative short-term mitigation measures and subsidies, and energy-pricing solutions. It is useful to distinguish between middle- or high-income countries where social safety nets exist and can be used for compensation and low-income countries, where ad hoc measures are often necessary. Also, the information needed to target support accurately is often not available in these countries, especially in urban area where geographic targeting is very inefficient (Kanbur, 2010).

Carbon pricing would have significant re-distributive impacts, among income- or wealth-classes, between rural and urban households, across regions and countries, and between consumers, workers, and shareholders. Three modeling exercises illustrate these effects. First, carbon pricing would have large redistributive impact across rural and urban households in Indonesia, which could require specific measures targeting poor rural households (Yusuf and Resosudarmo, 2007). Second, carbon pricing has inter-regional and income-class redistribution (Rausch et al., 2009; Hourcade et al., 2010), but these impacts could easily be compensated with changes in other taxes (e.g., labor tax or capital tax). Third, carbon pricing can have an impact on spatial inequalities within a city, with households dependent on individual transportation being affected more strongly; in that case, most of these negative impacts can be avoided by introducing carbon pricing slowly enough to allow land and housing prices to adjust (Gusdorf et al., 2008).

The consistent findings from studies on this issue are that: (i) the redistributive impacts of a carbon price scheme depend essentially on how revenues from the scheme are used; (ii) complementary measures are available to compensate for unintended distributional effects; (iii) these complementary measures meet the classical challenges of redistributive policies, mainly linked to political acceptability, imperfect information and targeting, and behavioral issues; (iv) a rapid and aggressive action is more likely to create negative distributional impacts than a slower and more predictable action.

The second factor is linked to the fact that environmental policies can influence output volatility. They can do so negatively, by creating a shock on the economy and by distorting inter-temporal trade-offs. They can do so positively by reducing potential risks to growth by increasing resilience to environmental shocks (such as natural disaster) or economic shocks (such as oil shocks, spikes in commodity prices, or loss of competitiveness due to innovation in another country). As a consequence, they can stabilize output and consumption, increasing welfare if risk aversion is accounted for. ${ }^{10}$

We can represent this factor by introducing the idea that future growth is subject to uncertainties that policymakers have to manage. These uncertainties include but are not restricted to uncertainty about

\footnotetext{
${ }^{10}$ For instance, Hallegatte (2011) suggests that development can be risk-increasing or risk-decreasing, depending on its structure and pattern. A green growth strategy will aim at making development risk-decreasing, thereby increasing the resilience of the economic system.
} 
the environment (e.g., climate change amplitude and patterns, risks from biodiversity losses, natural disasters); other major uncertainties include demographic changes, technological innovations, evolutions in preferences, and even policy performance. Taking into account these uncertainties, the production function and the utility function become partly stochastic, and the previous equations refer to their expected values:

$$
\begin{gathered}
Y=\psi\left(P_{E}\right) f\left(A\left(P_{E}\right), K\left(P_{E}\right), L\left(P_{E}\right), E\left(P_{E}\right), \xi_{1}\right) \\
U=u\left(C, E, P_{E}, \xi_{2}\right)
\end{gathered}
$$

where $\xi_{1}$ and $\xi_{2}$ are random variables, and $\xi_{1}<0$ and $\xi_{2}<0$ correspond to bad outcomes and df/d $\xi_{1}>0$ and $\mathrm{du} / \mathrm{d} \xi_{2}>0$. Note that these random variables not only include long-term environmental uncertainty (e.g. climate sensitivity), but also other shocks that negatively affect welfare or the economy (oil shocks, commodity price volatility, natural disasters, technological accident, etc.).

\section{Box 4: Energy efficiency and oil shocks}

In the 1970's oil shocks caused important macroeconomic fluctuations, but recent events suggest that the vulnerability of the world economy to oil shocks has decreased (Nordhaus, 2007). Several explanations can be put forward to explain the diminishing impact of oil shocks on economic growth. Blanchard and Gali (2008) and Gregorio et al (2007) identify the following factors: (a) the average oil-intensity of world GDP has decreased since the first two oil shocks, thus reducing vulnerability to oil prices; (b) labor markets - wages in particular - have become more flexible, so that oil shocks pass-through inflation is more difficult for a given monetary policy ; (c) the nature of oil shocks has changed, since the 73 and 79 shocks were caused by supply disruption while the 2008 shock was caused by increasing demand in emerging markets; (d) the low and stable inflation rate of these last decade have improved the agents' confidence in monetary policy and has stabilized inflation expectations.

Among these explanations, an obvious and important one is the decrease of GDP oil-intensity, which was driven by specific energy security policies. In some countries, higher taxes on gasoline consumption have reduced oil consumption; in others, other instruments like norms and regulations have reduced energy consumption by cars, industries, and in the residential sector. In all cases, these effects can be modeled as a decrease in $\mathrm{df} / \mathrm{d} \xi_{1}$, i.e. in the dependency of output (or GDP) on a random variable, here the price of oil.

Over the longer term, Rozenberg et al (2010) suggest that climate policies may have similar results: by driving technological change and investment away from oil-intensive patterns, they reduce oil consumption and vulnerability to oil shocks. Thus, climate policies can reduce the world vulnerability to oil scarcity and to the uncertainty in oil reserves. In particular, it might reduce the need for capital renewal in case of large change in energy prices, i.e. reduce the obsolescence of capital, which is represented by the term $\psi f_{K} K^{\prime}$ in Equation (2). Climate policies can then produce co-benefit of climate policies in terms of energy security and resilience.

In the same way, Gusdorf and Hallegatte (2007) show that cities that are developed with higher transportation taxes - and thus are denser and less energy consuming - are less vulnerable to volatility in future transportation prices. In Gusdorf et al. (2008), it is also shown that a rapid change in transportation costs can also have strong spatial and distributive impacts, with suburbs affected more strongly than urban centers (i.e., an impact through $\mathrm{du} / \mathrm{d} \xi_{2}$ because of distributive effects, in additional to the impact on aggregated consumption). 
A green growth agenda can help reduce the vulnerability of $U$ to $\xi_{1}$ and $\xi_{2}$, by reducing $d f / d \xi_{1}$ and $d u / d \xi_{2}$. Box 4 provides an example of how environmental policies targeting higher energy efficiency can reduce the economic vulnerability to oil shocks (both in terms of aggregate output and consumption, and in terms of distribution). In that case, the main benefit is environmental, but the resilience of the economy to other exogenous shocks (e.g., geopolitical tensions) is reinforced.

Taking into account this uncertainty, it is then possible to maximize the expected utility, $E\left[\mathbf{U}^{\infty}\right]$ :

$$
\operatorname{Max} E\left[\int e^{-\rho t} U(C, E)\right]
$$

Expected utility maximization is often considered to give low influence to worst-case (low-probability, large impacts) scenarios, whereas more risk averse decision-makers may prefer a maximin approach (aiming to maximize the utility that can be obtained in the worst possible situation).

\section{Trade-offs and Synergies}

The previous sections have shown that environmental policies can have costs, in terms of reduced output, consumption or welfare, as well as welfare or income benefits. The net impact will vary depending on the particular policy considered and the context. ${ }^{11}$

The balance between costs and benefits will also depend on how costs and benefits are defined. In a narrow economic framework, a policy to protect a mangrove forest will have an economic cost (for instance by preventing shrimp farming or tourism development), and no direct benefit. But in a framework that includes the valuation of ecosystem services, the policy will also have economic benefits from the valuation of the services the mangroves offer: protection against coastal storms, breeding ground for fisheries, wood resources for local community. As such, green accounting that include the valuation of ecosystem services offer a much better measure of trade-offs and are central to green growth strategies (Box 5).

Measuring the net impacts of green growth policies also critically requires capturing existing suboptimality due to market or government failures or to non-rational behaviors. Models based on firstbest assumptions (perfect markets, rational expectations, etc.) can usefully assess benchmark costs of these policies (i.e., what would they cost in a perfect world), but are unable to investigate the potential for co-benefits.

\section{Box 5: Green accounting}

With both production and utility defined as functions of the environment, it is useful to define measures of economic progress that encompass both produced and natural factors - to define 'green' national accounts. A large literature has dealt with both theory and practice on greening the national accounts (Aronsson and K-G Löfgren, 2010; Heal and Kriström, 2005; for a recent application see World Bank, 2011).

\footnotetext{
${ }^{11}$ For instance, models suggest that the GDP losses entailed by a carbon tax are very different, depending on how tax revenues are used (e.g., Goulder, 1995).
} 
To do so, there is a need to estimate shadow prices for environmental goods, including the values of in situ natural resources and the damages to production and welfare associated with the depletion and degradation of the environment. For commercial natural resources the shadow prices are readily estimated, and robust methods exist for valuing certain pollution damages, such as the damage to health associated exposure to air pollution. ${ }^{12}$ But for important natural assets, such as biodiversity, arriving at sound shadow prices is more problematic. In addition, ecological services are largely capitalized in existing asset values (pollination service values are capitalized in the value of farmland, for example), but not explicitly - for policy purposes it will therefore be useful to break out ecological service flows in extended national accounting systems. ${ }^{13}$

Key green accounting indicators include adjusted measures of net saving and net income. Savings measures adjusted for the depletion and degradation of the environment provide a measure of sustainability: if net saving is negative then social welfare - the present value of utility - is falling (Hamilton and Clemens 1999, and Dasgupta and Mäler 2000). Net income can then be measured as consumption, plus the direct contribution of the environment to wellbeing, plus net saving (Asheim and Weitzman 2001). ${ }^{14}$

Source: Kirk Hamilton

\section{Why not grow now and clean up later?}

Some dimensions of environmental quality improve with average income (e.g., air quality, water quality), while others do not (see the long debate on the environmental Kuznets curve). ${ }^{15}$ In this framework, one explanation for income-related environmental improvement is that the environment is a superior good: ${ }^{16}$ when $\mathrm{C}$ is low, the utility $\mathrm{U}$ does not depend much on $\mathrm{E}$. This would imply that poor people care less about the environment, give priority to economic consumption $C$ over environmental quality $E$, and act upon these preferences. At higher levels of consumption, with basic needs having being met, people will put a higher weight on the environment, leading to investments in environment protection and clean-up that will increase environmental quality, assuming the appropriate collective action proves possible:

$$
\frac{\partial^{2} U}{\partial E \partial C}>0
$$

This idea leads to the conclusion that environmental issues will "solve themselves" with economic development. In this framework, little effort is needed on environmental protection in poor countries, at

\footnotetext{
${ }^{12}$ For resource depletion, the United Nations (2003) is developing guidelines for green accounting. A recent paper by Muller et al. (2011) estimates the total value of pollution damages in a national accounting framework.

${ }^{13}$ See the WAVES partnership; http://go.worldbank.org/89A3W2FTU0. A good reference on environmental valuation is Freeman et al. (2003).

${ }^{14}$ The link between net saving and social welfare is only certain to hold if the accounting is complete, however, covering all assets which contribute to production or welfare.

15 The empirical literature on the Environmental Kuznets Curve (EKC) was triggered by Grossman and Krueger (1993, 1995). Early empirical contributions also include Selden and Song (1994), and Shafik \& Bandyopadhyay (1994); for a review, see Barbier (1997). Many subsequent work has aimed at deriving an EKC analytically, see, e.g. Stokey (1998); Andreoni and Levinson (2001); Brock and Taylor (2010).

${ }^{16}$ Another common interpretation is that the environmental Kuznets curve reflects structural transformation of an economy. As economies transform from largely agrarian to more industrial, environmental quality deteriorates. But as economies shift from largely industrial to more service-sector oriented, environmental quality improves.
} 
least for local public goods like water and air quality, and the focus needs to remain on economic production.

The "pollute now and clean up later" argument suffers from a number of weaknesses. Indeed, there are several situations in which early action may be desirable.

First, it may be more economical to start reducing or preventing pollution at an early growth stage rather than incurring all the cleanup costs at later stages, even when discounting is taken into account. This question is related to the role of technology and infrastructure lock-in, and is particularly important in developing countries where much of this century's infrastructure will be built in the next decades.

Second, it ignores the role of environmental irreversibility. When reversal is not possible, investments in environmental quality protection are necessary over the short term. This is the case for example in Kenya, where traditional forests are destroyed for bio-energy or agriculture. It is possible to restore their "water tower" and other functions through replanting but not their bio-diversity and tourism industry potential.

Third, the influence of environmental quality and welfare is often indirect, so people may not link water or soil quality to the health issues they are confronted with. ${ }^{17}$ Alternatively, populations may not internalize the public health benefits of a healthier environment. With better information on these indirect effects, they may ask for higher environmental quality at earlier stages of development. Public intervention may be needed to internalize the externality.

Fourth, even when they care (and evidence abounds that they do, given that they tend to be very vulnerable to environmental harm), poor communities may not have the "voice" to make their concerns heard. Implemented policies in developing countries may be more representative of the preferences of elites than those of the poor or reflect institutional constraints such as those imposed by poorly defined property rights (as in open access resources). More generally, it is difficult to infer preferences about collective goods from individual behavior. If cities offer many more jobs and opportunities than rural areas, but also much higher levels of local pollution, the fact that people move from rural areas to cities does not mean they would not prefer slightly less opportunities and higher environmental quality in cities. Their preferences are not completely revealed by the binary choice "moving or not to the city", because they do not have a continuum of choices of increasing opportunities and decreasing environmental quality. More generally, this example shows the limits of inferring individual preferences from observed behaviors, justifying the use of other tools such as surveys.

Finally, empirical evidence suggests that the hump-shaped environmental Kuznets curve applies to local pollution with short-term and visible impacts, but rarely to natural resource depletion (water resources) which have a long-term component or to global pollutants such as greenhouse gases (which combine a long-term component with a global scale). It seems likely that local environmental issues with short term manifestations get solved spontaneously as countries develop (e.g., local air and water pollution),

\footnotetext{
${ }^{17}$ In some case, even specialists debate the importance of these relationships.
} 
while global public goods with long-term consequences can keep getting worse (e.g. climate change and carbon emission, biodiversity).

\section{The analytical case for early action}

Minimizing costs and enhancing benefits may require early action, for two main reasons.

First, delaying action can be costly. In the climate change debate, the optimal timing of action is a research topic that has emerged from an evaluation of arguments in favor of postponing emission reduction (Nordhaus 1992, Wigley et al 1996). Those arguments include the risk of prematurelydepreciated investments if climate change turns out to be less threatening than expected, and the role of discounting. But other analyses suggest that early action is cheaper. For instance, Lecocq et al (1998) find that in absence of perfect foresight, specific early policies directed toward green infrastructure and long-lived capital are necessary to achieve mitigation objectives at a lower cost. Jaccard and Rivers (2007) also find that early action is preferable in long-lived capital sectors, like infrastructure and urbanization, even if marginal costs are higher there. Gusdorf and Hallegatte (2007) and Gusdorf et al. (2008) find that changing urban forms to make them less energy consuming is extremely costly (Box 4). Developing countries, therefore, would do well not to let their cities grow in a low-density, highindividual car-use patterns if their ultimate target for the end of this century is to have high-density and energy-efficient cities.

One measure of the importance of early action is provided by Davis et al. (2010), who assess the warming commitment due to existing energy infrastructure (i.e. the global warming that cannot be avoided without early scrapping of existing energy infrastructure). They find that this commitment is about $1.3^{\circ} \mathrm{C}$. Introducing infrastructure driving transport demand and non-CO2 gases, Guivarch and Hallegatte (2011) find that this commitment reaches $1.7^{\circ} \mathrm{C}$. These results show that maintaining climate change below a $2^{\circ} \mathrm{C}$ warming requires that almost no new infrastructure is designed disregarding climate change and that urgent action in needed in long-lived infrastructure. In absence of such action, delayed environmental policies will have to force the early replacement of physical capital (i.e., a decrease in $\mathrm{K}$ or an increase in capital depreciation), one of the main component of environmental policy cost that affects output through the channel $\psi f_{\mathrm{K}} \mathrm{K}^{\prime}$ (as mentioned earlier).

Others arguments for early action based on technical change reach different conclusions (Goulder and Mathai, 2000; Manne and Richels, 2004; Sue Wing, 2006). On the one hand, delayed action will be able to use better and cheaper technologies, and may be less expensive than early action. On the other hand, these better technologies will be developed only if serious commitments toward emissions reduction are made, and some technologies are now in the stage where learning-by-doing, economies of scale, and supported deployment is the best way of increasing productivity and reducing costs. In these cases, early action is justified by the technological changes that would be induced by this action (i.e., by the channel $\left.\psi f_{A} \mathrm{~A}^{\prime}\right)$. 
There are also cases in which early action is necessary to avoid irreversible environmental changes. ${ }^{18}$ This is the case of some ecosystems that cannot be recreated when they have been destroyed, or of species that cannot be saved once they have disappeared. It is indeed very likely that most biodiversity losses are irreversible, suggesting the need for immediate action in this domain (Chapin et al., 2000). This is also the case with climate change, since reachable objectives are less and less ambitious over time, in absence of stricter global climate policies. For instance, the $2^{\circ} \mathrm{C}$ objective is achievable only if significant emission reductions can be made before 2030 (e.g., Meinshausen et al., 2009; O'Neill et al., 2009). This irreversibility is a clear incentive for early action, since the consequences of warming exceeding $2^{\circ} \mathrm{C}$ are highly uncertain (see Ha-Duong et al., 1997, Ambrosi et al., 2003; World Bank, 2009).

Green Growth is about short to medium term policies. As a consequence, the identification of the actions that are much cheaper if implemented early is a key component of the development of any green growth strategy.

\section{Short term costs vs long term gains: tackling the political economy of GG}

When the benefits of environmental policies occur mainly over the long term or are global and diffuse rather than immediate and local, implementation is more difficult. The policy debate tends to focus on temporal trade-offs between short-term costs and long-term benefits.

Greening growth requires tackling the political and social acceptability of action. As such a green growth policy must seek to mitigate the temporal trade-offs in environmental policy design through shorterterm economic co-benefits highlighted earlier.

\section{Policy instruments design and green growth}

Green growth policies can be divided into three broad categories: the "getting the price right" policies; the "complement or replace prices" policies where markets signals can't be relied upon to effect the desired changes; and "activist" policies such as innovation or industrial policies.

\section{Getting the price right}

Environmental issues are often linked to "externalities", i.e. to the fact that the actors whose decisions impact the environment do not see the full impact of their choices and are not charged for the damages they cause. As a consequence, aligning prices with social values by "getting the price right" or "pricing the externality" is often considered as the main economic solution to these issues (Baumol, 1972; Baumol and Oates, 1971, 1988). Many instruments exist to do so, from taxes and subsidies (taxing the damages and/or subsidizing a reduction in damages) to tradable emission permit and the creation of property right markets. Box 1 provides an example in which setting a cap on the total allowable catch and creating a market (and thus a price) on fractions of this cap has been effective in making fisheries more sustainable.

\footnotetext{
${ }^{18}$ There is a debate about what «irreversible" means. Strictly speaking, over geological timescales, almost nothing is completely irreversible. Here, we label as "irreversible" the impacts that cannot be reversed over less than a few centuries.
} 
Getting the price right can also open doors for co-benefits in terms of economic growth and social welfare. Often environmental taxation (taxing "bads") and removing distortionary subsidies creates additional fiscal space to permit reduced taxation or subsidization of green public "goods" such public transport, renewable energy or green R\&D (see also the literature on the double dividend: e.g. Goulder, 1995; Parry and Bento, 2000). Thus in addition to generating some reduction in traffic, London's congestion tax has generated substantial resources to finance new investments in London's aging public transport system - thereby increasing the effectiveness of the price signal by reducing the costs or "disutility" associated with switching from single-car use to public transport.

Additional taxation or reduced subsidization can also have strong negative distributional impacts, and increase poverty. But the resources that can be drawn from them allow for compensating this effect (Box 3).

\section{Designing complementary policies}

Choosing the correct price is important but - in a second-best framework - such a measure may be insufficient or inapplicable, requiring complementary measures. (These complementary measures may in addition fix market failures and result in higher income and economic growth.)

First, it is often difficult to change prices to more appropriate values, including all externalities involved. Price changes generate strong opposition and may prove to be impossible for political economic and social acceptability reasons. As shown in Box 3, however, much can be done to enhance the political acceptability of measures, for instance by compensating or mitigating inappropriate distributional effects. Using existing safety nets or implementing specific measures to compensate the adversely-affected population can make it possible to increase prices up to a value that represents real social costs. In this case, the best approach from both political and economic perspectives may be policy mix including a change in price and a set of complementary measures to ensure the political and social acceptability of the new price.

Second, it is difficult to assess the correct prices, including all externalities. Bolt et al. (2005), Hanley and Barbier (2009), Pagiola et al. (2009) provide reviews of the various methodologies to infer the economic value of environmental goods and services that are not traded in actual markets. These methods have pros and cons, and are more or less appropriate depending on the context. However, they always involve significant uncertainties. In particular, it may be difficult to reach a consensus as to what the right prices is, considering the large ethical components of these prices when non-market values are included. Disagreement on valuation can make price changes difficult to implement in practice, and may require the use of alternative, non-price, policies.

Third, it has been observed that introducing taxation or prices can have negative consequences on behaviors. Behavior is driven not only by economic calculation but also by social values and intrinsic motivations. In some cases, the introduction of payment has been shown to reduce or cancel the motivation linked to social values and to have an impact on behavior opposite to that anticipated. This effect has been identified, e.g., by Gneezy and Rustichini (2000) who show that it is irreversible (i.e., the 
role of social values cannot be restored by removing the payment). As a consequence, they claim that to change behaviors, one should "pay enough, or not pay at all".

Fourth, and most important, many market imperfections can prevent prices from being the silverbullet of environmental policies. These include:

- Low price elasticity. The ability of prices to trigger changes in behavior and technological changes is sometimes limited by substitution possibilities: the responsiveness of drivers to higher fuel prices is low in the absence of alternative means of transport (Box 6). The responsiveness of renewable energy to feed-in tariffs will depend on whether transmission lines are built between centers of consumption and the location of renewable resources. In these cases, price-based policies may have to be complemented with direct investments in infrastructure (e.g., public transportation, transmission lines), and with additional policy actions, like changes in urban planning or in norms and regulations. Moreover, if substitution capacity is limited by alternatives, then the provision of these alternatives may increase the efficiency of the economy and increase income or promote economic growth. They may also make the increase in price more politically acceptable.

Box 6: Complementarities between price and non-price instrument in urban transport

Hoornweg et al. (2011) explain why price-based instruments alone may be inefficient, especially over the shortterm: "in the short run, energy pricing may not work, especially once consumers have made their purchases of equipment or vehicles. Short-term elasticities for energy demand are actually relatively low [...] because consumers are not influenced by price signals once they have locked in vehicle purchases and housing type and location, and often, location of employment. Long-run elasticities are more difficult to estimate and may underestimate the savings potential that result in changes in infrastructure systems, because of locked-in and long-lived capital investments.

Energy efficient cities, such as Hong Kong and Tokyo, have deliberately regulated individual car use and urban sprawl early on in their development. Without these efforts any reductions in energy consumption for transportation and household use resulting from price incentives would likely have been superseded by high income inelasticities for individual car use and high household energy consumption. Standard policy measures are not likely to lead to strong responses in greening cities, because elasticities for energy intensive activities, such as personal car ownership and housing location and type, are low. Infrastructure policies, which favor energy intensive housing or transport, have in fact reduced the responsiveness of citizens to fiscal and regulatory policies."

- Inertia in behavior is such that many energy efficiency measures that might pay for themselves are not implemented. For instance, households do not always react to an increase in energy price by improving building energy efficiency (see for instance, Train, 1985; Gillingham et al., 2009; Allcott and Mullainathan, 2010). Measures based on labels, information, and fiscal incentives may help influence behaviors. For instance, Abrahamse et al. (2007) presents the result from a study in which an internet-based tool is used to encourage households to save on their direct (gas, electricity and fuel consumption) and indirect (through transportation and goods consumption) energy consumption. The tool combines feedback on past consumption, energy saving tips, and goal setting. It is shown that this information helps households to reduce their direct energy consumption, and in the study households with access to the tool reduces their direct energy consumption by 5 
percent, while household with no access to the tool increase their consumption by 0.7 percent.

- Missing markets or institutions. Specific institutional measures can be required to transform the "right price" into the right incentive. Thus principal-agent issues can prevent tenants from improving their home energy efficiency (Box 7). These are also examples where correcting the environmental externality also correct an economic externality and increase efficiency.

\section{Box 7. Institutional schemes to distribute energy efficiency investments across tenants and owners.}

There is a large potential for cost-effective energy savings in the residential sector, and thus a potential for increasing the efficiency of the economy, represented by the term $\psi^{\prime} f$ in Equation (2).

In Germany, tenants represent $51 \%$ of households, which is the highest share in Europe. Moreover, two third of rented apartments are owned by households, social housing being only a minor part of the housing market (7\%). It is thus crucial to implement policies and measures to incentivize owners to improve energy efficiency in rented apartment. Rents are bounded by a reference rent at the beginning of the lease, and their increase during the lease is bounded by the "comparable regional rent", in $€ / \mathrm{m}^{2}$, for each city and as a function of the apartment characteristics. The law however authorizes rent increase during a lease, in case of investments that "increase quality of life" or "reduce water or energy consumption". In this case, the rent can reach $120 \%$ of the comparable regional rent. The rent increase is calculated on the basis of the "transferable" costs, equal to total investment costs reduced by what is considered a maintenance cost and by the financial support provided to owners. The rent increase is bounded at $11 \%$ per year of the transferable costs, which means that - for the owner - the investment is paid off in at most 10 years.

In France, the ADEME (Agence De l'Environnement et de la Maîtrise de l'Energie) provides examples of energy efficiency investments that have been shared between owners and tenants in a win-win manner. The private residence "Les Castors", in Bron, is composed of 4 buildings and 32 dwellings. The owner invested $430 \mathrm{k} €$ in energy efficiency in the building, half of that to improve energy efficiency (i.e. $100 € / \mathrm{m}^{2}$ or $7 \mathrm{k} €$ per apartment). Half of this additional investment cost was financed by government subsidies and the other half by a loan paid for by an increase in monthly rent of $€ 15$ per apartment on average. For the owner, the additional investment was paid for in 10 years and contributes to the value of the building. For tenants, the increase in rent was been more than compensated for by a $€ 35$ a month reduction in energy expenditure. To generalize this type of investment, the ADEME proposes a distribution rule for energy efficiency investment in building. Such a rule has to be (i) secure, i.e. it has to make sure that the overall housing cost does not increase for the tenant and that the owner can recoup its investment; (ii) transparent, i.e. includes only investment in energy efficiency and not normal maintenance costs; (iii) balanced, i.e. the cost transferred to tenants should not exceed owner investments; (iv) simple, i.e. easy to calculate to avoid costly legal conflicts between owners and tenants. The ADEME proposed rule is to have an annual transferred cost equal to $75 \%$ of the annual investment cost for the owner, in the limit of $75 \%$ of energy savings made by the tenant. The annual investment cost is equal to the annualized total investment costs reduced by the amount of financial support and the amount corresponding to normal maintenance expenditures.

Source: ADEME, Réhabilitation du parc locatif privé, Stratégie \& Etudes n¹8, February 2009. 
- Finally, price instruments may be difficult to put into practice, for technical or institutional-capacity reasons. For instance, market-based instruments like quotas have met technical problems in their implementation, even in regions with high capacity. This is the case of the European Trading System (Betz and Sato, 2006). In some case, alternative approaches may be simpler to implement and enforce, like norms, regulation, or other institutional innovation. Box 8 provides an example of an institutional innovation to deal with a classic tragedy of the commons problem, in the oil industry sector. However, the practical difficulties in implementing these alternative measures should not be disregarded. It is likely that different solutions are preferable in different countries with varying degree of institutional capacity, transparency, accountability and capacity of civil society. The implication is that green growth strategies will need to be tailored to a country's circumstances, and that "best practices" should be imported with caution.

\section{Box 8: Hot Oil and unitization}

The importance for overall economic performance of correcting environmental problems can be seen in the case of oil. In this case the term $\psi f_{E} E^{\prime}$ in equation (2) above captures the impact of environmental policy on the effective supply of natural capital and hence on the value of output. Oil provides also an example in which a solution has been identified that does not rely on prices or quotas, but on institutional innovation.

Under certain conditions oil becomes a common property resource. An oil field is a pool of oil beneath the earth. The shape of an oil field belowground does not always match the shape of the exploration and production licenses bought by oil companies, and several companies may buy the right to explore and produce the same field. Imagine, as a concrete example, an oil field that is ten miles square, $\mathbf{5 0 0}$ feet below ground, and contains twenty million barrels (roughly one day's consumption for the US). Oil company geologists know there is oil in this area, but don't know how much or the exact shape of the oilfield. Two oil companies buy exploration and production rights over this field, Company $L$ buying a ten by five mile concession covering the left half of the field and company $\mathrm{R}$ buying the same shape covering the right half of the field. So we have two drilling concessions sitting on top of one pool of oil. Once they start producing oil, both companies are extracting from the same pool of oil: there are twenty million barrels there and the more company L extracts the less remains for company $R$. So the oil is now a common property resource: one firm's "catch" comes entirely at the expense of the other's, an extreme case of a common property resource. The natural outcome, once the companies recognize that they are drawing from the same pool, is that they will rush to remove the oil from this as fast as possible. After all, the competitor will probably take any oil left behind.

This is in fact exactly how things happened in many US oil fields in the first third of the twentieth century, leading to serious consequences. Companies produced oil faster than they could sell it, and stored it aboveground, in storage tanks. Oil above ground is dangerous: it is inflammable, and can cause explosions, which is what happened. And storing oil is expensive, so companies had an incentive to sell it as fast as they were producing it, and this led to gluts of oil and sharp drops in its price, bad for long-term investment in oil sources. An additional drawback of this type of competition between firms to extract oil from the field, is that rapid extraction can damage the structure of the field and reduce the total amount of oil that can ultimately be removed: the faster you pull the oil out, the less you get, within limits. Oil produced in these competitive situations, and in excess of what the market could absorb, was known as "hot oil."

We just referred to a simple hypothetical example of two firms buying the right to explore and produce in one field. In fact matters got far worse than this: in the 1920 over 1,000 (one thousand!) firms had the right to explore 
and produce from the East Texas oil field, a single pool of oil, and between them they drilled 10,000 wells in their attempts to extract oil before their competitors. Most were small companies that have long since vanished or been absorbed into the oil majors: one had a fascinating name, the ITIO Company, Indian Territory Illuminating Oil Company, redolent of the days when oil was used in lamps and not cars. In the East Texas field competitive extraction lowered the pressure of the oil and gas in the field so fast that it was clearly damaging the prospects for recovering a reasonable fraction of the total, so the Governor of Texas stepped in and closed the field, using provisions of martial law, on two occasions, in August 1931 and December 1932. The East Texas field was an outlier in terms of the number of companies developing it and the degree of overexploitation, but it was not uncommon to find a dozen or more companies drilling into the same oil pool. To give another example, the Hendrick field in West Texas was developed by eighteen firms, who drilled on average one well per ten acres, whereas one well per eighty acres would have drained the field rapidly.

For all these reasons, regulators sought ways of solving the problem, and in many cases adopted the solution of unitization. Unitization means that the companies owning different parts of an oil field all agree to operate it as one single company, rather than as many competing entities. In our example, companies $L$ and $R$ would set up a new company which owns the entire oil field, say the LR Oil Field Company, with each having $50 \%$ of the shares in this (shareholdings are generally prorated to the amounts of the field owned). LR would then operate the field as a single company, following an extraction policy that makes long-run economic sense.

Unitization has worked in the US: a study compared the productivity of twenty oil fields in Arkansas, Louisiana, Oklahoma and Texas, ten of which were developed before unitization and ten after. After fifteen years of production, output from the earlier group has declined to just 8.6 percent of peak output, whereas that of the later group was still at $\mathbf{7 3 . 9}$ percent of peak. Before unitization could be legally required, it was possible for all the firms drilling into a field to get together and agree on a common development policy: this tended to happen when there were only a few companies involved in a field, but not when there were many, as for example in the East Texas field. The problems of reaching a policing an agreement were insuperable with such huge numbers.

In sum, it is useful to distinguish two cases. When prices can be adjusted to reflect social costs, then additional complementary policies are often necessary to support substitution, influence behaviors, and translate the price into the right incentive, or to correct some undesirable effects of the price change (e.g., the distributional impact). When prices cannot be adjusted for technical or political reasons, alternative policies can replace them, but specific care should be devoted to the risks from rebound effect: with inappropriate prices, implementing norms to increase energy efficiency can reduce energy bills and incentivize less responsible behaviors. In that case, a combination of norms and "behaviorbased" policies might be more efficient than norms only.

\section{Activist policies: innovation and industrial policies}

Knowledge externalities and learning effects are critical to how we deal with environmental protection, and justify complementing price-based instruments with R\&D support (Gerlagh, 2006; Otto et al., 2008; Fischer and Newell, 2008; Acemoglu et al., 2011).

Economies of scale, concentration externalities, coordination failures, information asymmetry, capital market imperfections, and technological lock-in effects are such that price incentives would need to be uneconomically high to stimulate the needed investments. Also, current prices may be ineffective to stimulate investments with long term pay-offs, justifying the use of multiple instruments, especially 
targeting long-lived capital (Vogt-Schilb and Hallegatte, 2011). Indeed, sector-scale policies can help develop technologies or change practices without having to set a very high price for the externality. Box 9 summarizes Japan's experience to promote energy efficiency, using a mix of objective setting, benchmarking, norm and regulations, $R \& D$, and direct investments.

These types of industrial policies may usefully complement price-based policies, even though there are risks associated with them. In particular, the role of government failures (see discussions in the climate domain in Anthoff and Hahn, 2010 and Helm, 2010) needs to be accounted for in the same way than market failures are included. Activist policies create a risk from capture and rent-seeking behaviors (Laffont, 1999) that need to be considered. For a comprehensive survey of industrial policies in developing countries, see Harrison and Rodriguez-Clare (2010).

\section{Box 9. Japan's energy efficiency strategy: an example of sector-scale policy}

Building on its excellent track record in energy conservation since the first oil shock (the energy use per unit of GDP has decreased 26 percent between 1980 and 2009), Japan has pledged to go further with the "Energy Conservation Law" enforced in 2006. The law seeks to improve energy efficiency (already one of the highest in the world) by 30 percent in 2030 relative to 2006. The aim is double: protecting the environment, and improve the efficiency of the economy (represented by the term $\psi^{\prime} f$ in Equation (2)).

To reach such a target, the plan outlines a strategy to foster energy conservation technologies and develop and disseminate a benchmarking approach in order to correctly monitor energy conservation. More precisely, the strategy seeks to (i) introduce the most advanced technologies for replacing equipment in the energy sector, (ii) make net-zero-energy houses available by 2020 (and the norm nationwide by 2030), and (iii) introduce new integrated standards for energy consumption in all buildings.

Interestingly, the national strategy also contains the Top Runner Program, which is a very innovative policy to raise energy efficiency standards. The program sets standards for 21 products (e.g. vending machines, air conditioners, television sets, etc.) sold in Japan. On a regular basis, officials test all the products available in a category, determine the most efficient model, and make that model's level of efficiency the new baseline. Then, manufacturers have the obligation to make efforts to achieve the new baseline within four to eight years. If a manufacturer does not meet the target or fails to make a good faith effort, this fact is publicized. Conversely, products which have reached the energy efficiency standard receive a "Top Runner" label.

Furthermore, the newest innovation in energy efficiency is the concept of "smart community". A smart community is a model city that maximizes the use of renewable energy (such as PVs, wind power and micro hydraulic) and heavily relies on smart grids to deal with its intermittent nature. Four large-scale pilot projects were started in Japan in 2010. For instance, in Fukuoka, the deployment of energy conservation systems for an entire town will involve a real-time energy management for 70 companies and 200 households using smart meters. In Kansai Science City, an active deployment of electric vehicles will be undertaken, with the construction of a network of charging station. The Japan Smart Community Alliance brings together private companies from the power, automobile, and IT sectors, as well as the construction industry, the public sector, and academia. Japan is also seeking to export this concept: a project is under way in India and a "smart community plan" has been signed between Japan and China. 
Source: METI (Ministry of Economy, Trade and Industry) website http://www.meti.go.jp/ and World Resource Institute website http://www.wri.org.

\section{Conclusion}

Green policies are adopted to deliver environmental benefits - such as public health in China or combating desertification in Niger-which are expected to increase welfare. The first category of benefits from green policies is thus the economic benefits from a better environment, including the amenities derived from it and the use of natural capital as a production factor.

Most of these policies are also likely to have an economic cost over the short term, such as higher investment or operational costs. These costs create trade-offs between environmental protection and economic growth. But environmental policies can also sometimes yield economic benefits and contribute to growth, by correcting existing sub-optimalities and market failures. The "green growth" idea is to reconcile the short and the long term, and to offset short-term costs by maximizing synergies and economic benefits (e.g., job creation and poverty alleviation, increased efficiency) and by mitigating trade-offs across both space and time. Doing so, it tries to make environmental policies easier to implement in spite of political obstacles, and to increase the social and political acceptability of environmental policies.

Of course, green growth cannot be disconnected from the welfare measurement issue. Even when environmental policies increase welfare (or even wealth) over the short term, they may lead to a decrease in GDP, for instance because of a change in investment structure or higher reliance on (nonmeasured) ecosystem services. Wealth and green accounting are thus essential tools to help design green growth policies (see Box 5). But they are not a requirement for implementing environmental policies.

In the absence of a comprehensive, consensual, and operational wealth accounting, our Green Growth approach is to screen green policies through the following check-list, to investigate whether it is possible to design policies differently to obtain - in addition of environmental benefits - short term benefits in one of the five following categories:

- Increase in production factors, especially natural capital, and human and social capital, through improvements in health, education, cohesion, and stability.

- Shifting the production frontier (i.e. being able to produce more with less) and making the economy cleaner, through correcting market failures in innovation development and dissemination and improving knowledge spillovers in the entire economy.

- Making the economic more efficient, i.e. correcting market failures to get closer to the production frontier with existing technologies, and thus reduce production costs and increase competitiveness (including stimulus during periods of under-utilization of resources). 
- Increasing resilience to environmental shocks, such as natural disaster, and economic shocks, such as oil shocks, or spikes in commodity prices.

- Increasing the job content and poverty alleviation of growth, i.e. moving toward "inclusive growth."

These co-benefits and the environmental benefits can be captured in many ways. In a Green Growth framework, getting the price right is important, but is likely to be insufficient or inapplicable. Indeed, it is often politically difficult to change prices to more appropriate values, and many market failures explain why prices cannot be the silver-bullet of environmental policies. Because of these failures, it is necessary to complement price-based policies with other policies. Additional policy instruments such as norms and regulation, public production and direct investment, information creation and dissemination, education and moral suasion, or industrial policies and the setting of long-term targets can also be useful. Since green growth policies pursue a variety of goals, they are best served by a combination of instruments.

Specific work is required to analyze the various policies that can meet these goals, and to assess the actual extent of synergies that can be achieved. This paper is about a framework to assess green growth opportunity. Only policy- and context-specific studies can provide quantified estimates of the synergies and trade-offs that are implied by a green growth strategy.

\section{References}

Abrahamse, W., L. Steg, C. Vlek, T. Rothengatter, 2007. The effect of tailored information, goal setting, and tailored feedback on household energy use, energy-related behaviors, and behavioral antecedents. Journal of Environmental Psychology 27 (2007) 265-276

Acemoglu D, Aghion P, Bursztyn L, Hemous D., 2011. The environment and directed technical change. American Economic Review, in press.

Aghion, P. and P. Howitt, 1992. A model of growth through creative destruction. Econometrica 60(2), 323-351.

Allcott, H. and S. Mullainathan, 2010. Behavior and energy policy, Science 327, 1204-1205.

Ambec, S., M. A. Cohen, S. Elgie, and P. Lanoie, 2011. The Porter Hypothesis at 20: Can Environmental Regulation Enhance Innovation and Competitiveness? Resources for the Future, Washington D.C., USA.

Ambrosi P., Hourcade J.-C., Hallegatte S., Lecocq F., Dumas P., Ha Duong M., 2003. Optimal control models and elicitation of attitudes towards climate damages. Environmental Modeling and Assessment 8(3):133-147.

Andreoni, J., and A. Levinson, 2001. The simple analytics of the Environmental Kuznets Curve. Journal of Public Economics 80 (2), 269-286. 
Anthoff, A. and Hahn, R., 2010. Government failure and market failure: on the inefficiency of environmental and energy policy. Oxford Review of Economic Policy 26 (2), 197-224

Aronsson, T. and K-G Löfgren eds. 2010. Handbook of Environmental Accounting. Cheltenham: Edward Elgar.

Arrow, K. J., 1962. The economic implications of learning by doing. The Review of Economic Studies 29 (3), 155-173.

Asheim, G.B., and M.L. Weitzman, 2001. Does NNP Growth Indicate Welfare Improvement? Economics Letters 73:2, pp. 233-39.

Barbier, E., 1997. Environmental Kuznets Curve special issue: Introduction". Environment and Development Economics 2, 369-381.

Baumol, W. and W. Oates, 1988. The Theory of Environmental Policy, (2nd edition) Cambridge University Press, Cambridge.

Baumol, W., 1972. On Taxation and the Control of Externalities, American Economic Review, 62(3), 307321.

Betz, R., and M. Sato, 2006. Emissions trading: lessons learnt from the 1st phase of the EU ETS and prospects for the 2nd phase. Climate Policy 6(4), 351-359.

Blanchard, O. J., Gali, J., 2010. The Macroeconomic effects of Oil Price Shocks: Why are the 2000s so Different from the 1970s?

Bolt, K.; Ruta, G. and M. Sarraf, 2005, Estimating the Cost of Environmental Degradation, The World Bank.

Bourguignon, F. and Fields, G. 1990. Poverty Measures and Anti-poverty Policy. Recherches Economiques de Louvain, 56(3-4), pp. 409-427.

Bovenberg, A. L. and Sjak Smuldters. 1996. Transitional Impacts of Environmental Policy in an Endogenous Growth Model, Int. Econ. Rev. 37:4, pp. 861-95.

Bowen, A., 2011. Green growth, green jobs, and labour market. Background paper for the SDN Flagship Report on Green Growth. The World Bank, Washington, DC.

Brock, W.A., and Taylor, M.S. 2005. Chapter 28 Economic Growth and the Environment: A Review of Theory and Empirics Aghion, P. \& Durlauf, S. N. (ed.) Elsevier, Vol. 1, Part 2, pp. 1749-1821

Brock, W., and Taylor, M. 2010. The Green Solow model , Journal of Economic Growth, Springer Netherlands, Vol. 15(2), pp. 127-153-153.

Camerer, C. and H. Kunreuther, 1989. Decision Processes for Low Probability Events: Policy Implications. Journal of Policy Analysis and Management, 8, 565-592. 
Chapin, F. S., III, E. S. Zavaleta, V. T. Eviner, R. L. Naylor, P. M. Vitousek, H. L. Reynolds, D. U. Hooper, S. Lavorel, O. E. Sala, S. E. Hobbie, M. C. Mack, and S. Diaz. 2000. Consequences of changing biodiversity. Nature 405:234-242.

Coady, D., M. El-Said, R. Gillingham, K. Kpodar, P. Medas, and D. Newhouse, 2006: The magnitude and distribution of fuel subsidies: evidence from Bolivia, Ghana, Jordan, Mali, and Sri Lanka, IMF Working Paper WP/06/247, Washington, DC.

Costello, C., Gaines, S. D. \& Lynham, J., 2008. Can Catch Shares Prevent Fisheries Collapse? Science 321, 1678-1681 (2008).

Croitoru, Leila and Maria Sarraf, Eds. 2010. The Cost of Environmental Degradation: Case Studies from the Middle East and North Africa. The World Bank, Washington DC

Dasgupta, P., and G. Heal, 1974. Optimal Depletion of Exhaustible Resources. Rev. Econ. Studies, Symposium (1974), pp. 3-28.

Dasgupta, P., and K-G Mäler, 2000. Net National Product, Wealth, and Social Well-Being. Environment and Development Economics 5, Parts 1\&2:69-93, February \& May 2000.

Davis, K., S.J. Caldeira, H. D. Matthews. Science 329, 1330-33 (2010).

Fischer, C., R. G. Newell, 2008. Environmental and technology policies for climate mitigation, Journal of Environmental Economics and Management, Volume 55, Issue 2, Pages 142-162.

Foa, R., 2009. Social and Governance Dimensions of Climate Change Implications for Policy, Policy Research Working Paper 4939, The World Bank.

Freeman, M. III, J. Herriges and C. Kling, 2003. The Measurement of Environmental and Resource Values: Theory and Methods. 2nd Ed. Washington DC: RFF Press.

Freund, C. L., and C. I. Wallich, 1995: Raising household energy prices in Poland. Who gains? Who loses? Policy Research Working Paper 1495, The World Bank, Washington, DC.

Gali, J. and M. Gertler (eds.), 2008. International Dimensions of Monetary Policy. University of Chicago Press, Chicago, IL, Ch.

Gerlagh R., 2006. ITC in a Global Growth-Climate Model with CCS. The Value of Induced Technical Change for Climate Stabilization, The Energy Journal, Special issue on Induced Technological Change and Climate Change, 55-72.

Gillingham, K., R. Newell, and K. Palmer (2009): “Energy Efficiency Economics And Policy," Annual Review of Resource Economics, 1, 597-619.

Gneezy, U. and Rustichini, A. (2000), "Pay Enough Or Don't Pay At All", Quarterly Journal Of Economics, 115 (3), 791-810. 
Goulder L.H., Mathai K (2000) Optimal CO2 abatement in the presence of induced technological change. Journal of Environmental Economics and Management 39(1):1_38

Goulder, L. (1995), “Environmental Taxation and the ‘Double Dividend': A Reader's Guide,” International Tax and Public Finance 2(2).

Graff Zivin, J.S., and M. J. Neidell, 2011. The impact of pollution on worker productivity, NBER Working Paper 17004.

Gregorio, J. D., O. Landerretche, and C. Neilson, 2007. Another pass-through bites the dust? Oil prices and inflation," mimeo, 2007.

Grossman, G.M., Krueger, A.B. (1993). "Environmental impacts of a North American free trade agreement". In: Garber, P. (Ed.), The US-Mexico Free Trade Agreement. MIT Press, Cambridge, MA, pp. 57-125.

Grossman, G.M., Krueger, A.B. (1995). "Economic growth and the environment". Quarterly Journal of Economics 110 (2), 353-377.

Grubb M., Chapuis T., Duong MH (1995) The economics of changing course: Implications of adaptability and inertia for optimal climate policy. Energy Policy 23(4-5):pp. 417-431

Guivarch C., S. Hallegatte, 2011. Existing infrastructure and the $2^{\circ} \mathrm{C}$ target, Climatic Change Letters, in press.

Gusdorf, F., S. Hallegatte, 2007. Compact or Spread-Out Cities : Urban Planning, Taxation, and the Vulnerability to Transportation Shocks, Energy Policy, 35 (2007) 4826-4838.

Gusdorf, F., S. Hallegatte, A. Lahellec, 2008: Time and space matter: how urban transitions create inequality, Global Environment Change, 18(4), 708-719.

Ha-Duong M., M.Grubb ,J.-C. Hourcade (1997) Influence of socioeconomic inertia and uncertainty on optimal CO2-emission abatement. Nature 390(6657):270-273

Hallegatte, S., 2011. How economic growth and rational decisions can make disaster losses grow faster than wealth, Policy Research Working Paper 5617, The World Bank

Hallegatte, S., J.-C. Hourcade, P. Dumas, 2007, Why economic dynamics matter in assessing climate change damages: illustration on extreme events, Ecological Economics, volume 62(2), 330-340

Hamilton, K., and M. Clemens, 1999, Genuine Savings Rates in Developing Countries. The World Bank Economic Review, 13:2, pp. 333-56.

Hanley, N. and E. B. Barbier, 2009, Pricing Nature: Cost Benefit Analysis and Environmental Policy. Cheltenham, UK: Edward Elgar. 
Hanna, R., 2011. The Effect of Pollution on Labor Supply: Evidence from a Natural Experiment in Mexico City, NBER Working Paper 17302.

Harberger, A.C., 1978: On the use of distributional weights in social cost-benefit analysis. Journal of Political Economy, 86(2).

Harrison, A.E. and A. Rodriguez-Clare (2010), "Trade, Foreign Investment, and Industrial Policy", Handbook of Development Economics. Volume 5, Pages 4039-4214.

Heal, G. and Kriström, B. 2005. Chapter 22 National Income and the Environment, Mäler, K.-G. \& Vincent, J. R. (ed.) Elsevier, Volume 3, Part 2, pp. 1147-1217

Heal, G. and Schlenker, W., 2008. "Economics: sustainable fisheries", Nature 455, 1044-1045.

Helm, D. 2010. Government failure, rent-seeking, and capture: the design of climate change policy. Oxford Review of Economic Policy 26 (2), 182-196.

Hogarth, R., and H. Kunreuther, 1995. Decision Making Under Ignorance: Arguing with Yourself. Journal of Risk and Uncertainty, 10, 15-36.

Hoornweg, Daniel, Mila Freire, Marcus J. Lee, Perinaz Bhada-Tata, and Belinda Yuen. 2011. Cities and Climate Change: Responding to an Urgent Agenda. The World Bank.

Hope, E. and B. Singh, 1995: Energy price increases in developing countries: case studies of Columbia, Ghana, Indonesia, Malaysia, Turkey, and Zimbabwe, Policy Research Working Paper 1442, The World Bank, Washington, DC.

Hourcade, J.-C., F. Ghersi, E. Combet, D. Thery, 2010: Carbon Tax and Equity : The Importance of Policy Design, in Dias Soares, C., Milne, J., Ashiabor, H., Deketelaere, K., Kreiser, L. (ed.), Critical Issues in Environmental Taxation, Oxford University Press, Oxford, pp. 277-295.

Jaccard M, Rivers N (2007) Heterogeneous capital stocks and the optimal timing for CO2 abatement. Resource and Energy Economics 29(1):1-16

Kanbur, R., 2010: Macro crisis and targeting transfers to the poor. In Globalization and Growth: Implications for a Post-Crisis World, Commission on Growth and Development, The World Bank, 342pp, Washington, DC.

Laffont JJ (1999) Political economy, information, and incentives. European Economic Review 43:649-669.

Lecocq F, Hourcade J, Ha Duong M (1998) Decision making under uncertainty and inertia constraints: sectoral implications of the when flexibility. Energy Economics 20(5-6):539-555

Lucas, R. E., Jr., 1988. On the Mechanics of Economic Development, Journal of Monetary Economics, 22: 3-42. 
Magat,W., K.W. Viscusi, and J. Huber, 1987. Risk-dollar trade-offs, risk perceptions, and consumer behaviour. In: Learning About Risk [Viscusi, W. and W. Magat (eds.)]. Harvard University Press, Cambridge, MA, 83-97.

Malthus,T. R. (1965).First essay on population. New-York: Kelley. (Original work published 1798)

Mankiw, N.G., D. Romer, D. N. Weil, 1992. A Contribution to the Empirics of Economic Growth, The Quarterly Journal of Economics, 107(2), 407-437

Manne A, Richels R (2004) The impact of learning-by-doing on the timing and costs of CO2 abatement. Energy Economics 26(4):603-619

Meinshausen, M., Meinshausen, N., Hare, W., Raper, S., Frieler, K., Knutti, R., Frame, D. Allen, M., 2009. "Greenhouse-Gas Emissions Targets for Limiting Global Warming to 2ํㄱ", Nature 458, pp. 1158-62.

Milanovic, M., 2011. The Haves and the Have-Nots. A Brief Idiosyncratic History of Global Inequality, Basic Books, 2011

Muller, NZ., R. Mendelsohn and W. Nordhaus, 2011, Environmental Accounting for Pollution in the United States. American Economic Review 101:1649-1675.

Nordhaus WD, 1992. An optimal transition path for controlling greenhouse gases. Science 258(5086):1315-1319

Nordhaus, W.D. 1974. "Resources as a Constraint on Growth." American Economic Review 64: 22-26.

O'Neill, B. C., Riahi, K. \& Keppo, I. Mitigation implications of midcentury targets that preserve long-term climate policy options. Proc. Natl Acad. Sci. USA 107, 1011-1016 (2009).

Otto, V.M., and Reilly, J., 2008. Directed technical change and the adoption of CO2 abatement technology: the case of $\mathrm{CO} 2$ capture and storage. Energy Economics. 30, 2871-2890. doi:10.1016/j.eneco.2007.07.001.

Pagiola S., von Ritter K. and J. Bishop, 2005. Assessing the Economic Value of ecosystem Conservation, Others 0502006, EconWPA.

Parry, I. W. H. \& Bento, A. M., 2000. "Tax Deductions, Environmental Policy, and the "Double Dividend" Hypothesis," Journal of Environmental Economics and Management, Elsevier, vol. 39(1), pages 6796, January.

Popp D., R.G. Newell, and A.B. Jaffe, 2009. Energy, the Environment, and Technological Change, NBER Working Papers 14832, National Bureau of Economic Research, Inc

Porter, M., and C. van der Linde (1995), Toward a New Conception of the Environment-Competitiveness Relationship, Journal of Economic Perspective 9(4), 97-118. 
Rausch S., G. E. Metcalf, J.M. Reilly, and S. Paltsev, 2009: Distributional impacts of a U.S. greenhouse gas policy: a general equilibrium analysis of carbon pricing, Report 182, MIT Global Change Science and Policy.

Rodrik, D. and A. Subramanian, 2008. Why did financial globalization disappoint? Mimeo. Harvard University and Peterson Institute for International Economics.

Romer, Paul M., "Endogenous Technological Change," Journal of Political Economy, 1990, 98, S71-102.

Romer, Paul M., "The Origins of Endogenous Growth," The Journal of Economic Perspectives, Vol. 8, No. 1 (Winter, 1994) pp. 3-22

Rozenberg J., S. Hallegatte, A. Vogt-Schilb, O. Sassi, C. Guivarch, H. Waisman, J.-C. Hourcade, 2010, Climate policies as a hedge against the uncertainty on future oil supply, Climatic Change Letters, 101(3), pp. 663-669.

Selden, T., Song, D. (1994). "Environmental quality and development: Is there a Kuznets curve for air pollution emissions?". Journal of Environmental Economics and Management 27, 147-162.

Sen, A. K., 1973: On the Development of Basic Income Indicators to Supplement the GNP Measure. United Nations Economic Bulletin for Asia and the Far East, September-December 1973b, 24(2-3), pp. 1-11.

Sen, A.K., 1976: Poverty: An Ordinal Approach to Measurement. Econometrica, 44(2), pp. 219-23.

Shafik, N., Bandyopadhyay, S. (1994). Economic Growth and Environmental Quality: Time Series and Cross Country Evidence. The World Bank, Washington, DC.

Small, K.A., et K. Van Dender. 2007. « Long run trends in transport demand, fuel price elasticities and implications of the oil outlook for transport policy ». OECD/ITF Joint Transport Research Centre Discussion Papers.

Smulders, J. (1994). Growth Market Structure and the Environment: Essays on the Theory of Endogenous Economic Growth. Tilburg University, Tilburg.

Smulders, S. (1999). "Endogenous growth theory and the environment". In: van den Berg, J.C.J.M. (Ed.), Handbook of Environmental and Resource Economics. Edward Elgar, Cheltenham, pp. 610-621.

Smulders, S. 2005, Endogenous Technological Change, Natural Resources, and Growth, Chapter 8 in "Natural Resources and the Environment in the New Millennium", R.D. Simpson, M.A. Toman, and R.U. Ayres (eds), The Johns Hopkins University Press for Resources for the Future.

Solow, R. M. , 1956. A contribution to the theory of economic growth. Quarterly Journal of Economics, 70, 65-94.

Solow, R. M., 1974. The Economics of Resources or the Resources of Economics. American Economic Review 64: 1-14. 
Stokey, N. (1998). "Are there limits to growth". International Economic Review 39 (1), 1-31.

Sue Wing, I. (2006) Representing induced technological change in models for climate policy analysis. Energy Economics 28(5-6):539-562

Train, K., 1985, "Discount rates in consumer's energy-related decisions: a review of the literature", Energy, 10(12):1243-1253

Tversky, A. and E. Shafir, 1992. Choice under conflict: the dynamics of deferred decision. Psychological Science, 3(6), 358-361.

United Nations 2003. Handbook of National Accounting: Integrated Environmental and Economic Accounting 2003. New York: United Nations.

Vogt-Schilb A., S. Hallegatte, 2011. When Starting with the Most Expensive Option Makes Sense: Use and Misuse of Marginal Abatement Cost Curves. Policy Research Working Paper 5803, The World Bank.

Wigley TML, Richels R, Edmonds JA (1996) Economic and environmental choices in the stabilization of atmospheric CO2 concentrations. Nature 379(6562):240-243

World Bank, 2006. Where is the Wealth of the Nations? The World Bank, Washington D.C.

World Bank, 2009. World Development Report 2010: Development and Climate Change. World Bank, Washington DC.

World Bank. 2009. World Development Report 2010: Development and Climate Change. World Bank Publications.

World Bank 2011. The Changing Wealth of Nations: Measuring sustainable development in the new millennium. Washington DC: The World Bank.

Yusuf, A.A., and B. Resosudarmo, 2007: On the distributive effect of carbon tax in developing countries: the case of Indonesia, Working Paper in Economics and Development Studies, Padjadjaran University.

Zenghelis, D., 2011. A macroeconomic plan for a green recovery, Policy paper, Grantham Research Institute on Climate Change and the Environment. 